\title{
O consumo de arroz em Portugal e a rizicultura americana (1750-1808)
}

\section{Rice consumption in Portugal and American rice plantations (1759-1808)}

Alberto Camargo Portella ${ }^{1}$

Cereal domesticado em locais tão variados quanto o oeste da África e a Ásia, o arroz, desde o século VIII, passou a ser produzido em solo europeu. Em Portugal, contudo, quando comparado a cereais consumidos e produzidos de modo usual, como o trigo, o arroz levou um longo tempo para ocupar um espaço decisivo nos hábitos alimentares da população. No século XVIII, o cereal já havia angariado relevante espaço nas mesas portuguesas das mais variadas condições. Seu principal emprego se manteve, todavia, substitutivo. Ou seja, a importação de arroz tomava força, normalmente, quando havia carestia de grãos consumidos de forma habitual (sobre o assunto, ver as obras de Judith Carney, O arroz africano na história do Novo Mundo, de 2017, pp. 183-185; Peter Coclanis, Distant Thunder: the creation of a world market in rice and the transformation it wrought, de 1993, pp. 1052-1054; Nuno Ferreira, A alimentação portuguesa na idade medieval, de 2008, p. 106; Carlos Veloso, A alimentação em Portugal no século XVIII nos relatos dos viajantes estrangeiros, de 1992, pp. 29-103; Kenneth Morgan, The organization of the colonial American rice trade, de 1995, p. 436).

Uma relevante parcela da demanda portuguesa, antes e durante parte do período considerado na pesquisa, foi atendida, por um lado, pelo arroz produzido na Península Itálica. Por outro, havia remessas de arroz produzido, por exemplo, na colônia britânica da Carolina do Sul a partir do século XVII (sobre o assunto, ver as obras de Judith Carney, O arroz africano na história do Novo Mundo, de 2017, pp. 185-188; e Dauril Alden, Manoel Luís Vieira: an entrepreneur in Rio de Janeiro during Brazil's eighteenth century agricultural renaissance, de 1959, p. 534).

Todavia, a partir de meados dos setecentos, ao proporem reformas na administração imperial, intelectuais e agentes governativos portugueses tiveram como um de seus objetivos a substituição de importações que pesavam sobre a balança comercial. O arroz, nesse contexto, não foi negligenciado. Essa transformação, não analisada com vagar pela historiografia, é o foco da pesquisa de mestrado em andamento, que cobre um período que se estende de 1750, com o início das reformas ilustradas portuguesas, até o ano de 1808 (ver Fernando Novais, Portugal e Brasil na crise do Antigo Sistema Colonial, 1777-1808, 2011, pp. 213-298).

Para avaliar tal mudança, a pesquisa analisará os discursos econômicos, surgidos nas reformas em Portugal, que tiveram como um de seus alvos a diversificação da produção agrícola imperial (incluindo o arroz). Sendo assim, escritos de intelectuais luso-americanos e de agentes governativos do império serão essenciais na pesquisa. Ademais, com o fim de avaliar a adequação entre os planos e a realidade agrícola na América portuguesa, as correspondências trocadas entre as autoridades imperiais, que versaram sobre os problemas da agricultura americana, serão centrais na análise (ver Fernando Novais, Portugale Brasil na crise do Antigo Sistema Colonial, 1777-1808, 2011, pp. 213-298). 
Palavras-chave: arroz; diversificação agrícola; mercado mundial; Portugal; século XVIII. Keywords: rice; agricultural diversification; world market; Portugal; $18^{\text {th }}$ century.

1 Mestrando em História Social na Universidade de São Paulo, bolsista Fapesp (processo 2019/12541-2). 